\title{
Peter Bro
}

\author{
Birgitte Kjos Fonn: \\ 50 år med journalistutdanning: \\ en historie om akademiseringen av et yrkesfag. \\ Oslo: Cappelen Damm. 2015
}

MedieKultur 2016, 61, 185-187

\section{Published by SMID | Society of Media researchers In Denmark | www.smid.dk The online version of this text can be found open access at www.mediekultur.dk}

Fornemmelsen af at have forvildet sig ind til en lukket fest for norske medie- og journalistikforskere er fremherskende ved første gennemlæsning af Birgitte Kjos Fonns bog 50 år med journalistutdanning: en historie om akademiseringen av et yrkesfag. For den 304 sider lange monografi rummer hundredevis af henvisninger til norske mediepersoner og -organisationer, som har haft betydning for udviklingen af landets journalistuddannelser.

Henvisningerne starter allerede på første side. Her kan man læse om Carl Just, der var foregangsmand for de norske journalistuddannelser. Han drev i årevis Norsk Korrespondanseskoles brevkursus i journalistik, etablerede senere en privat journalistskole ved navn Journalistakademiet og forfattede også landets første lærebog i Journalistik. Men i bogen får Carl Just siden følgeskab af utallige henvisninger til politikere, uddannelsesledere, forskere, undervisere, studerende, redaktører, journalister, formænd for brancheorganisationer og mange andre, og det udfordrer læseoplevelsen.

Men kan man som dansk læser frigøre sig fra fornemmelsen af at sidde med de norske journalistik- og medieforskeres svar på Den Blå Bog, så venter en spændende og fagligt nærende læseoplevelse. For beskrivelsen af, hvordan journalistikken har udviklet sig som akademisk fag i Norge, rummer også mange pointer og tankevækkende perspektiver for kolleger $\mathrm{i}$ andre lande, som er optaget af forskning, undervisning og relationen til verdenen udenfor universiteterne. 
Omdrejningspunktet for Birgitte Kjos Fonns bog er Norsk Journalistskole, der blev etableret i Oslo i 1965, og som fejrede 50 års jubilæum i 2015, hvor denne bog udkom. Bogen henviser ganske vist undervejs i de tre hoveddele og de 19 kapitler til andre journalist- og medieuddannelser i Norge. Der er eksempelvis faglige og geografiske afstikkere til alt fra Bodø til Bergen. Men forfatteren - der selv er ansat på, hvad hun betegner som landets "første og største" uddannelse, som i dag hedder Høgskolen i Oslo og Akershus - bruger kendskabet til sin egen arbejdsplads klogt.

Det betyder, at bogen ligeså meget fremstår som en professionshistorie som en egentlig institutionshistorie, og centralt i historien er de mange magtkampe om, hvad journalistik er, hvem journalister er, og ikke mindst hvordan faget og dets fremtidige udøvere skal formes. De magtkampe er i mange af bogens fremhævede tilfælde blevet næret af en grundlæggende konflikt mellem fagets praktikere og dets akademikere; og det uanset om kampene har udspillet sig på den politiske arena, i journalistuddannelsernes bestyrelseslokaler eller $\mathrm{i}$ selve undervisningslokalerne.

For nok var mange af mediebranchens mest fremtrædende personligheder i midten af forrige århundrede kommet til en erkendelse af, at faget trængte til en grundigere uddannelse end de brevkurser, som Carl Just udbød. Selvom Just gjorde sit for at løfte fagligheden i norske medier. Just anslog selv, at han nåede, at eksaminere mellem 8.000 og 9.000 journalistkursister gennem sin karriere. Men både internt i den norske mediebranche og i forhold til de første personer, som skulle forestå uddannelsen af fremtidens journalister, var der uenighed om mangt og meget.

Hvad der siden fulgte af magtkampe for at påvirke uddannelsen af journalister i Norge, har Birgitte Kjos Fonn kortlagt ved at konsultere et stort antal mundtlige og skriftlige kilder. Det er blandt andet blevet til 67 interviews og indsigt i årtiers udgivelser af fagblade, referater fra møder og rapporter, lovforslag og andre former for skriftlige kilder. Kildematerialet giver gode eksempler på, hvad de forskellige parter i, hvad man med nogen ret kan karakterisere som akademiserings-konflikten, har hæftet sig ved gennem det sidste halve århundrede.

En tidlig kritiker af, hvad den nye uddannelse kunne føre med sig, fremhævede, at studerende kan miste "seg selv. De har fătt avslipt sitt personlige preg, sin individualitet. De er blitt et slags standardmennesker, et produkt bygget på lærebøker, litteraur, pensum, skolenes autoritet og eksamener. Ofte er de uten en selvstendig tanke." Omvendt lød det fra tilhængerne af uddannelsen, at undervisningen kunne blive og måtte være noget andet og mere end bare en "overføring av profesjonens tilvante måter å tenke og arbeide på," hvis man skulle bistå med den faglige udvikling af faget.

Men kampen om journalistuddannelserne stod ikke kun mellem kræfter udenfor og indenfor uddannelsesinstitutionerne. Den blev også kæmpet blandt medarbejdergrupperne - mellem forskellige grupper af fagligheder. I den første tid efter etableringen af Norsk Journalistskole blev undervisere ansat til at varetage enten "journalistisk praksis" eller "journalistisk teori", og det er et fagskel, som vi kender den dag i dag. Også fra danske jour- 
nalistuddannelser, hvor nogle arbejder ud fra en erfaringsbaggrund - også kaldet håndværkerne - og andre ud fra en forskningsbaggrund.

Med tiden og den gradvise tilnærmelse til de norske universiteter, hvor interessen for mediernes virke også bredte sig henover sidste del af 1900-tallet, har akademiseringen af de norske - såvel som de danske - journalistuddannelser taget fart. Men dengang - som i dag - fulgte midlerne til forskning ikke naturligt med. I 1982 havde man eksempelvis kun NOK 18.000 afsat til forskning på Norsk Journalistskole. Det beløb er trods alt blevet større siden da, og det samme er antallet af studerende, studiernes længde og de studerende forskningsbaserede indlæringstid.

Birgitte Kjos Fonn runder i bogens Efterskrift udviklingen af ved at konstatere, at man i de senere år har taget endnu et skridt mod akademiseringen af journalistikken. For nu har man ikke alene ansat sine egne forskere på Høgskolen i Oslo og Akershus og på andre journaliststudier. Man har også etableret formaliserede uddannelsesaftaler med flere af landets universiteter, sådan som det kendes fra Danmark, hvor DMJX, Danmarks Medie- og Journalistuddannelse, samarbejder med Århus Universitets medievidenskabsmiljø omkring udbuddet af kandidatuddannelser.

Men det hører med til historien, både i Norge, Danmark og andre skandinaviske lande, at udviklingen faktisk også er gået den anden vej i den periode, som bogen beskriver. For samtidig med journalistuddannelsernes tilnærmelse til universiteterne, har flere universiteter tilnærmet sig journalistikken. I dag har flere universiteter egne journalistuddannelser, og som led i den proces har universiteterne i praksis taget et skridt i retning af en af-akademisering, idet man $\mathrm{i}$ tiltagende grad har ansat undervisere, hvis faglighed er baseret på journalistisk erfaring snarere end på forskning.

Den udvikling beskriver Birgitte Kjos Fonn ikke. For denne udgivelse er i særlig grad skrevet med afsæt i hendes nuværende arbejdsplads, der også har støttet publiceringen af bogen. Men teksten fortjener status som mere end blot et jubilæumsskrift. For den rummer pointer, der vækker tanker og ægger til refleksioner omkring journalistikkens udvikling, som har en langt større rækkevidde og relevans, end hvad der er foregået på de skiftende Oslo-adresser for Norges første og største journalistuddannelse.

Peter Bro

Professor (mso), ph.d.

Leder af journalist-uddannelserne på SDU ppe@journalism.sdu.dk 